\title{
ARCHIWALIA
}

\section{LIST TADEUSZA KANTORA}

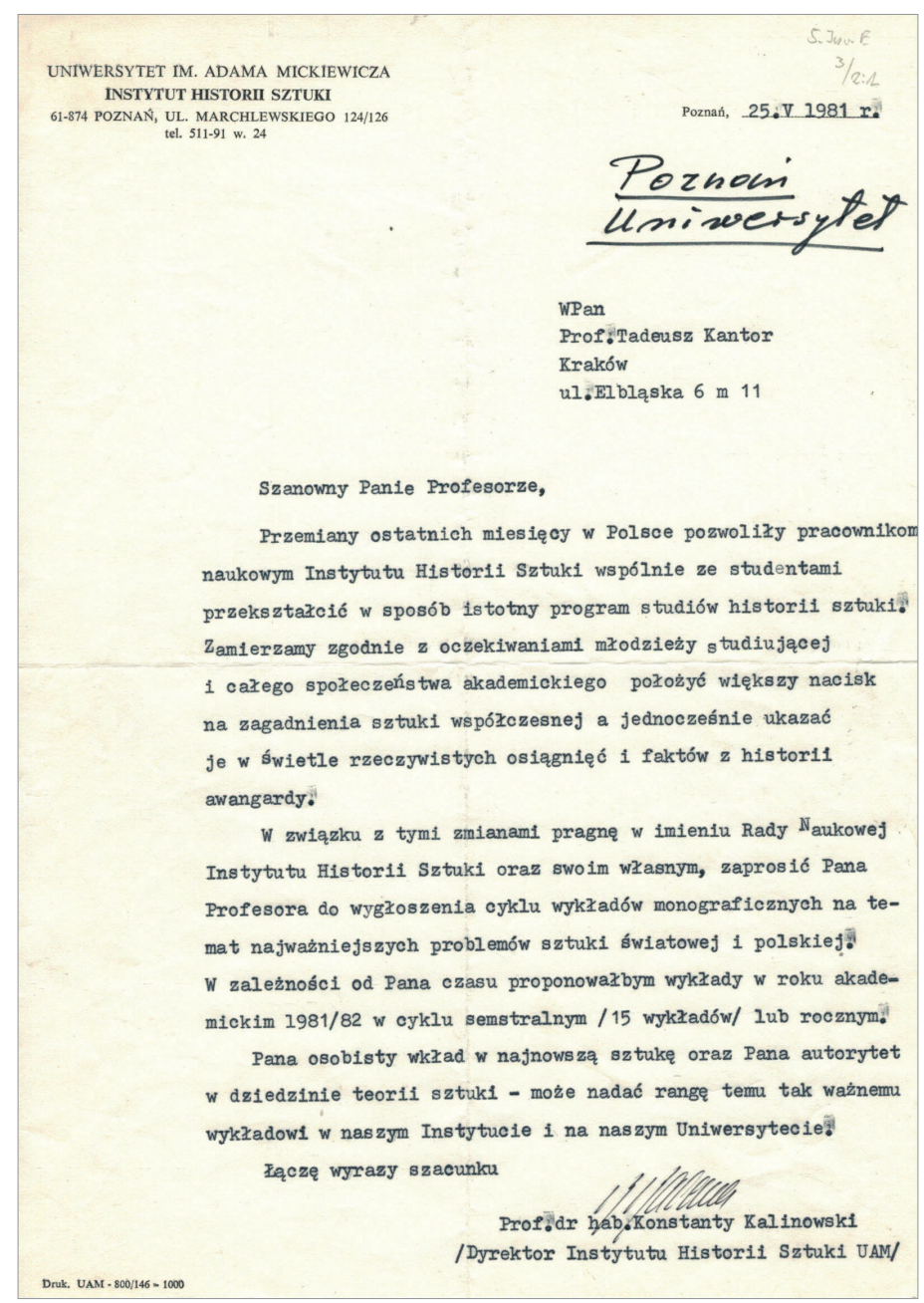

List dyrektora Instytutu Historii Sztuki UAM prof. Konstantego Kalinowskiego do Tadeusza Kantora, będący zaproszeniem artysty do wygłoszenia cyklu wykładów. 25 maja 1981. Publikacja dzięki uprzejmości Fundacji im. Tadeusza Kantora. Specjalne podziękowania dla pana Lecha Stangreta za odnalezienie tego dokumentu. 


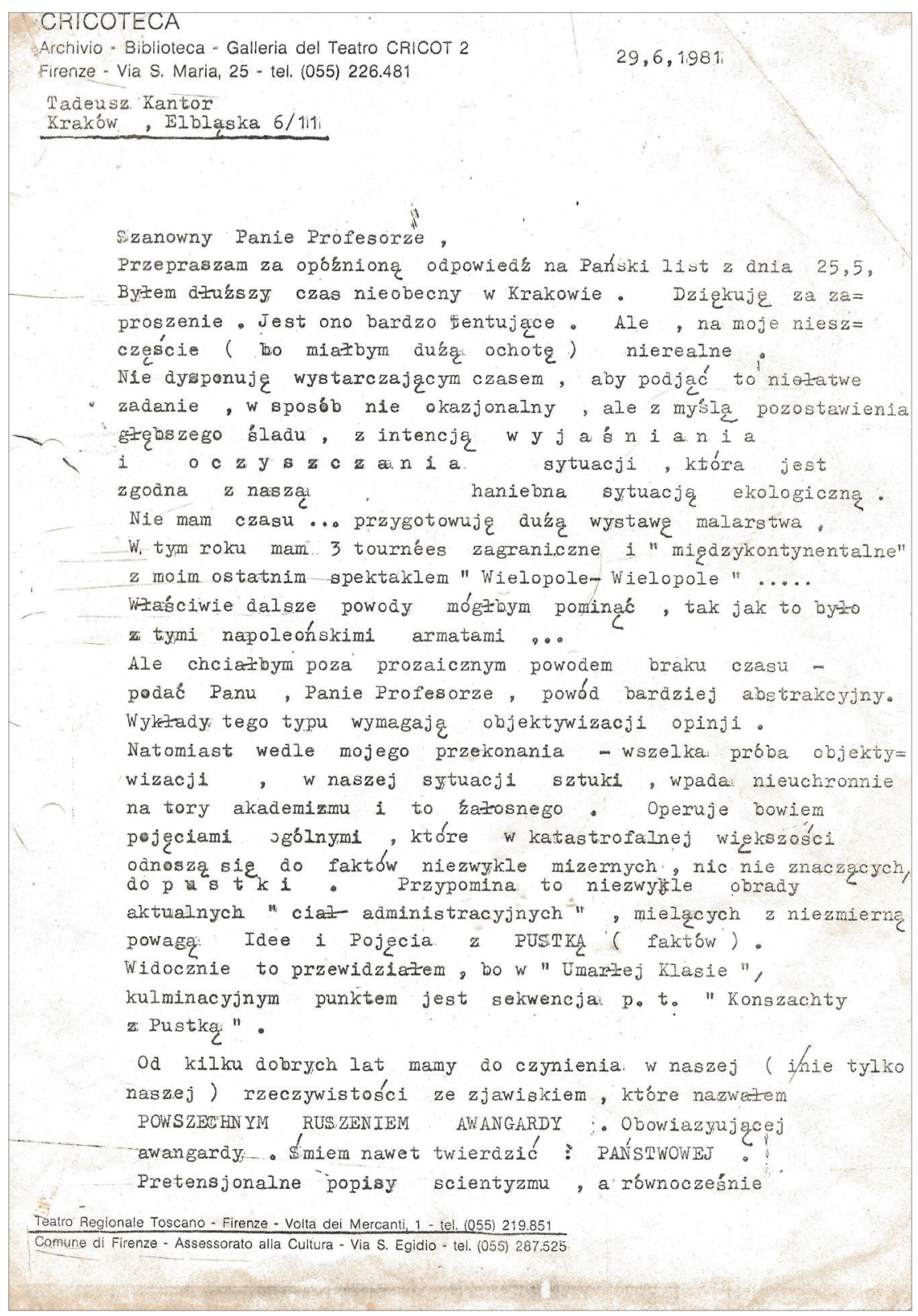

List z 29 czerwca 1981 roku stanowi odpowiedź skierowaną do prof. Konstantego Kalinowskiego, ówczesnego dyrektora Instytutu Historii Sztuki UAM, na listowne zaproszenie artysty do wygłoszenia wykładu w poznańskim Instytucie.

Dokument znajduje się w archiwum Instytutu Historii Sztuki UAM w Poznaniu. Za zwrócenie na niego uwagi Redakcja serdecznie dziękuje Pani Grażynie Zwolińskiej. 


\section{CRICOTECA}

Archivio - Biblioteca - Galleria del Teatro CRICOT 2

Firenze - Via S. Maria, 25 - tel. (055) 226.481

płytika, zaweziona inteligencja, nikły format myslowy, prowincjonalne " zadufanie ", i to s,co najgorsze, czego się jakoś dziwnie nie zauwaka, bo widocznie. wigze sie z pojeciem literatury : GR A F O M A I A.

Za parawanem awangardowości - najzwyklejszy znany nam jak dobrze konformizm.

Brak kompletny śmiałosci, aby przeciwstawiak sie powszechnej

konwencji i normom . Brak tej rooralności która postulowaz suxrealizm.

Aby zakonczyć ten index : nieobecnoš tego, co decyduje - sztuce : przeczucie NIEZNANEGO i NIENOZILIWEGO. Czyli W Y O B R A z N I A

Sytuacja jest bezpriykładna, to znaczy nie maprecedensów historycznych. I jeszcze jedno: odpowiada jota w jote naszej rzeczywistości socjalnej : Idea postępu skompro= mitowana przez jej amoralny i przestepczy aparat W sztuce : idea awangardy skompromitowana przez pospolitość myślenia i prymitywizm powszechnej,

- standardowej pseudo- awangardy .

W naszym źyciu nazywamy probę wyjścia z tej sytuacji - d n w a Wielka nasza szansa w kulturze swiatowej. W sztuce jest o wiele trudniej. Nie moźna upraszozać. Przed kilku laty doszedłem do przekonania, ze sztuka Ścislej mowiąc: sztuka plastyczna, jej "nack yn $j e^{\prime \prime}$ I sie w które wlewa Fyywioz naszego ŚWIATA - jest dzisiaj, z jakichs tam powodbw, za ciasne, niezdolne przyjać w siebie ogromu konfliktów naiszej epoki.

Dlatego szukałem innego " naczynia ". Znalaziem je we formi nowego teatru, która wasciwie nim nie jest. W "Umarłej Klásie " w 1975 roku i teraz. W "Wielopolu Wielopolu " dałem pierwsz̨, moze jeszcze nie zupełnie pe odpowiedź. Widzę ze wiare pisania, list przekształca sie w traktat. Dlatego kończe : 


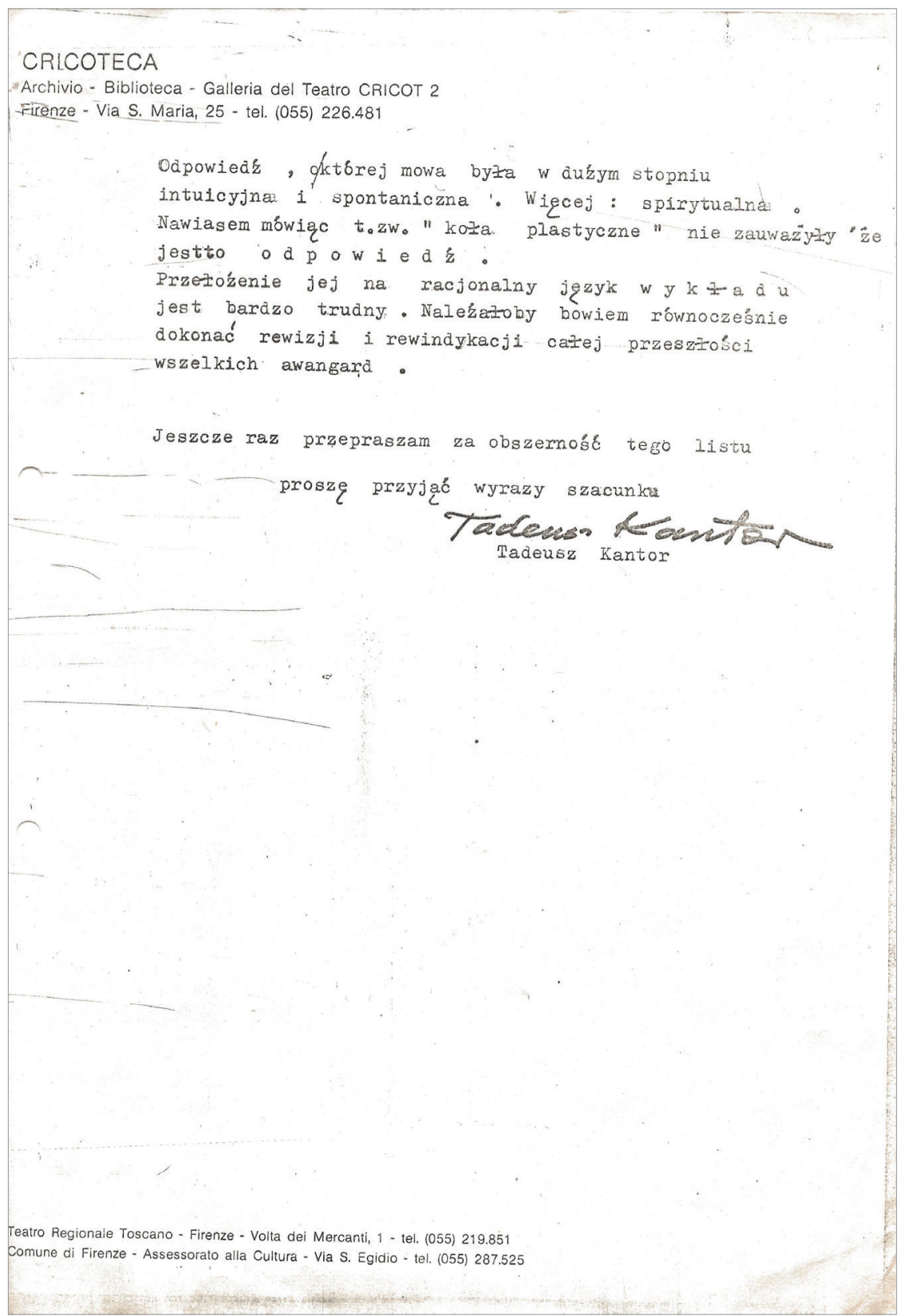

